\title{
Gil J. Stein. «Persians on the Euphrates? Material Culture and Identity in Two Achaemenid Burials from Hacinebi, Southeast Turkey »
}

\section{Astrid Nunn}

\author{
(2) OpenEdition \\ Journals \\ Édition électronique \\ URL : http://journals.openedition.org/abstractairanica/42565 \\ DOI : 10.4000/abstractairanica.42565 \\ ISBN : 1961-960X \\ ISSN : 1961-960X \\ Éditeur : \\ CNRS (UMR 7528 Mondes iraniens et indiens), Éditions de l'IFRI
}

\section{Référence électronique}

Astrid Nunn, « Gil J. Stein. « Persians on the Euphrates? Material Culture and Identity in Two Achaemenid Burials from Hacinebi, Southeast Turkey » », Abstracta Iranica [En ligne], Volume 37-38-39 | 2018, document 8, mis en ligne le 10 mars 2018, consulté le 28 septembre 2020. URL http://journals.openedition.org/abstractairanica/42565; DOI : https://doi.org/10.4000/ abstractairanica.42565

Ce document a été généré automatiquement le 28 septembre 2020.

Tous droits réservés 


\title{
Gil J. Stein. « Persians on the Euphrates? Material Culture and Identity in Two Achaemenid Burials from Hacinebi, Southeast Turkey »
}

\author{
Astrid Nunn
}

\section{RÉFÉRENCE}

Gil J. Stein. « Persians on the Euphrates? Material Culture and Identity in Two Achaemenid Burials from Hacinebi, Southeast Turkey », in Michael Kozuh, Wouter F. M. Henkelman, Charles E. Jones, Christopher Woods (eds.). Extraction \& Control: Studies in Honor of Matthew W. Stolper. Studies in Ancient Oriental Civilization 68. Chicago, The Oriental Institute of the University of Chicago, 2014, p. 265-286.

1 Deux sépultures intactes d'époque achéménide ont été découvertes sur le site de Hacinebi, situé sur l'Euphrate, en Turquie mais non loin de la frontière syrienne, à un passage fréquenté depuis des millénaires. Torques à têtes d'animaux, boucles d'oreilles à granulé, bagues, scarabée et alabastre, tous sont typiques de la culture matérielle achéménide "internationalisée ». Vue la synthèse d'éléments éparts, il est difficile d'identifier l'appartenance ethnique de toute sépulture individuelle. L'A. étudie non seulement les objets mais aussi les tombes dans le contexte plus large de l'Empire perse. Leur richesse signale une élite locale. En conclusion l'A. penche vers la thèse controversée - de P. Moorey selon laquelle les personnes inhumées étaient, comme à Deve Hüyük, des soldats perses en poste avec leur famille. 


\section{AUTEURS}

\section{ASTRID NUNN}

Université de Munich 